Instituto Internacional de Investigación y Desarrollo Tecnológico Educativo INDTEC, C.A.

DOI: https://doi.org/10.29394/Scientific.issn.2542-2987.2018.3.7.0.6-15

OAI-PMH: http://www.indteca.com/ojs/index.php/Revista Scientific/oai

\title{
Las prácticas investigativas contemporáneas. Los retos de sus nuevos planteamientos epistemológicos
}

$\mathrm{PhD}$. José Ignacio Herrera Rodríguez Universidad Nacional de Educación, UNAE

joseighr2015@gmail.com

Chuquipata, Ecuador

\section{Editorial}

El desarrollo científico técnico en la contemporaneidad configura un nuevo pensamiento investigativo. Desde esta mirada, los abordajes cuantitativos son acompañados de comprensiones fenomenológicas para la explicación de los procesos. Mientras que en las investigaciones cualitativas intervienen recursos y técnicas cuantitativas de medición y explicación.

Una de las problemáticas que enfrentan los investigadores a la hora de organizar un proceso investigativo es la de seleccionar una metodología pertinente con la naturaleza del objeto/sujeto de estudio. Esta selección los lleva a tomar partido a favor de procesos de naturaleza cuantitativa o cualitativa, con puntos de vista plurales en dependencia de las maneras de percibir y comprender el panorama que tienen ante sí. Además, se debe propiciar la conformación de un andamiaje de métodos y técnicas de corte positivista, fenomenológico o donde se exprese una complementariedad entre ambos.

Un ejemplo lo tenemos en el estudio de la conducta humana donde no podemos perder de vista la naturaleza causal que origina el comportamiento humano y la peculiar combinación de la herencia y del medio ambiente, los motivos y la orientación hacia metas y objetivos conscientes. En este estudio, puede ser pertinente la utilización de métodos y técnicas cuantitativos, así como aquellos que exploren la subjetividad humana.

El debate epistemológico entre los paradigmas racionalistas y empirista carece de base suficiente, pues los métodos particulares no están 
necesariamente vinculados a un paradigma.

El paradigma positivista también llamado (cuantitativo, empíricoanalítico, racionalista) busca explicar, predecir, controlar los fenómenos, verificar teorías y leyes para regular los fenómenos; identificar causas reales, temporalmente precedentes o simultáneas.

Por su parte, la racionalidad hermenéutica (cualitativo, fenomenológico, naturalista, humanista o etnográfico) busca una forma de abordar, estudiar, entender, analizar y construir conocimientos; a partir de procesos de interpretación donde la validez y la confiabilidad del conocimiento descansa, en última instancia, en el rigor del investigador. Se asume la construcción del conocimiento como un proceso subjetivo e intersubjetivo. En tanto, es el sujeto quien construye el diseño de investigación, recopila la información, la organiza y le da sentido desde sus estructuras conceptuales previas; así como los hallazgos que surgen de la propia investigación, que luego se colectivizan y se discuten en la comunidad académica.

Erlandson, Harris, Skipper y Allen (1993), contraponen el diseño tradicional (cuantitativo) al diseño emergente (propio de la indagación derivada del paradigma naturalista). La diferencia entre ambos se halla en la especificidad del plan original de investigación.

Si la investigación cualitativa busca comprender significados; los estudios cuantitativos tratan de conocer cuestiones poco exploradas a través de la eficacia de las técnicas.

Stake (1999:41), señaló:

"Esta distinción entre métodos cuantitativos y cualitativos es una cuestión de énfasis - ya que la realidad es la mezcla de unos y otros. En cualquier estudio etnográfico, naturalista, hermenéutico u holístico (por ej., en cualquier estudio cualitativo) la enumeración y reconocimiento de la diferencia de cantidad ocupan un lugar destacado. $Y$ en cualquier estudio estadístico o experimento controlado (por ej., en cualquier estudio cuantitativo) son importantes el lenguaje 
natural con que se describen y la interpretación del investigado".

Para Hashimoto y Saavedra (2014:8), "La discusión tiene que centrarse en por qué debo o tengo que usar ese u otro método, o en el para qué debo buscar o emplear ese dato o método". Ese es el quid del asunto, resolver esa cuestión está en el plano filosófico y no metodológico.

Guba y Lincoln (2002:113), plantean:

"Desde nuestra perspectiva, el uso de métodos tanto cualitativos como cuantitativos puede ser apropiado para cualquier paradigma de investigación. De hecho, las cuestiones de método son secundarias frente a las de paradigma, que definimos como el sistema básico de creencias o visión del mundo que guía al investigador ya no sólo a elegir los métodos, sino en formas que son ontológicas y epistemológicamente fundamentales".

El tema de la complementariedad metodológica transita por el dilema de la ausencia de fundamento epistemológico de base para aproximarse a la realidad. McMillan y Schumacher (2005:128-129), señalan que la investigación cuantitativa está basada en alguna forma de positivismo lógico que busca establecer cómo son las cosas evitando juicios de valor; mientras que la investigación cualitativa está basada en el construccionismo, que busca explicar cómo las personas llegan a describir, explicar o dar cuenta del mundo donde viven. Estas dos tradiciones muchas veces son vistas como antagónicas y sin posibilidades de discusión o cooperación.

La propuesta de complementariedad entre los dos paradigmas puede considerarse como una opción válida en la investigación; pues cada una de las metodologías hace importantes aportes a la construcción de conocimientos. Su uso rígido, sin dudas, empobrece el proceso de búsqueda de nuevos conocimientos, al impedir incorporar al proceso investigativo las bondades que cada uno de ellos posee e impide llegar a hallazgos más 
interesantes.

Las posibilidades de complementación pueden darse sustentadas en los principios de consistencia y de unidad dialéctica. Lo cuantitativo en su lógica hipotético-deductiva aporta al proceso la explicación y la relación de causa y efecto. A su vez, lo cualitativo con su comprensión inductivo-deductiva se adentra en los complejos caminos de la construcción y la decodificación de significados de la subjetividad humana, que considera lo individual y lo grupal, como resultado de los procesos sociales que cada uno vive. Por tanto, la complementariedad nos permite aprovechar las fortalezas de un método para compensar las debilidades del otro.

Tomando en consideración a Serrano, Blanco, Ligero, Alvira, Escobar y Sáenz (2009:16-17), “...el uso combinado de ambas perspectivas en el seno de una misma investigación ha pasado a convertirse en un lugar comúnmente aceptado y que se ha llegado incluso a un momento en el que podemos hablar de la "deseabilidad social" de la investigación multimétodo".

Los focos temáticos de este volumen de la Revista Scientific. muestran claramente sus diferentes secciones, entre ellas: la transformación de las prácticas docentes; las experiencias innovadoras para perfeccionar los procesos educativos y de enseñanza-aprendizaje en el marco del aula; los entornos virtuales de aprendizaje, las tecnologías de la información y las comunicaciones y la relacionada con la educación ambiental. Hacia allí conducen las preguntas que recorren los diversos artículos como testimonio de los resultados científicos que cada autor propone.

En sus enfoques epistemológicos se aprecia un recorrido por diferentes metodologías, métodos y técnicas. Se transita desde miradas cuantitativas, cualitativas o de complementación metodológica; respetando, como se ha referido anteriormente, la naturaleza del objeto de la investigación realizada.

Finalmente, la importancia de las temáticas de este número de la Revista radica en la reflexión acerca de las disímiles aristas de los procesos 
formativos, en variados contextos y niveles de enseñanza. También reside en la mirada a las lógicas en uso, comprometidas con diferentes metodologías; las cuales deben juzgarse en correspondencia al éxito alcanzado en las investigaciones.

Palabras clave: editorial; investigación; desarrollo científico. 


\section{Contemporary investigative practices. The challenges of his new epistemological approaches}

\section{Editorial}

The scientific and technical development in contemporaneity configures a new investigative thought. From this perspective, quantitative approaches are accompanied by phenomenological understandings for the explanation of processes. While qualitative research involves resources and quantitative measurement and explanation techniques.

One of the problems that researchers face when organizing an investigative process is to select a methodology that is relevant to the nature of the object / subject of study. This selection leads them to take sides in favor of processes of a quantitative or qualitative nature, with plural points of view depending on the ways of perceiving and understanding the panorama before them. In addition, the conformation of a scaffolding of methods and techniques of positivist or phenomenological cut or where a complementarity between both must be expressed.

We have an example in the study of human behavior where we can not lose sight of the causal nature that originates human behavior and the peculiar combination of heredity and the environment, the reasons and the orientation towards conscious goals and objectives. In this study, the use of quantitative methods and techniques may be relevant, as well as those that explore human subjectivity.

The epistemological debate between rationalist and empiricist paradigms lacks a sufficient basis, since particular methods are not necessarily linked to a paradigm.

The so-called positivist paradigm (quantitative, empirical-analytical, rationalist) seeks to explain, predict, control phenomena, verify theories and laws to regulate phenomena; identify real, temporally preceding or simultaneous causes. 
On the other hand, hermeneutic rationality (qualitative, phenomenological, naturalistic, humanistic or ethnographic) seeks a way to approach, study, understand, analyze and build knowledge; from processes of interpretation where the validity and reliability of knowledge rests, ultimately, on the rigor of the researcher. The construction of knowledge is assumed as a subjective and intersubjective process. In the meantime, it is the subject who constructs the research design, collects the information, organizes it and gives it meaning from its previous conceptual structures; as well as the findings that arise from the research itself, which are then collectivized and discussed in the academic community.

Erlandson, Harris, Skipper and Allen (1993), contrast traditional (quantitative) design with emergent design (typical of the inquiry derived from the naturalist paradigm). The difference between the two lies in the specificity of the original research plan.

If qualitative research seeks to understand meanings; quantitative studies try to know little explored issues through the effectiveness of techniques.

Stake (1999: 41), noted:

"This distinction between quantitative and qualitative methods is a matter of emphasis - since reality is the mixture of one and the other. In any ethnographic, naturalistic, hermeneutical or holistic study (eg, in any qualitative study) the enumeration and recognition of the difference in quantity occupy a prominent place. And in any statistical study or controlled experiment (eg, in any quantitative study) the natural language with which they are described and the interpretation of the researched are important".

For Hashimoto and Saavedra (2014: 8), "The discussion has to focus on why I should or have to use that or another method, or in what I should look for or use that data or method". That is the crux of the matter, to resolve this question is on the philosophical and not methodological level. 
Guba and Lincoln (2002: 113), state:

"From our perspective, the use of both qualitative and quantitative methods may be appropriate for any research paradigm. In fact, questions of method are secondary to those of paradigm, which we define as the basic belief system or worldview that guides the researcher and not only to choose the methods, but in ways that are ontological and epistemologically fundamental".

The theme of methodological complementarity goes through the dilemma of the absence of basic epistemological foundation to approach reality. McMillan and Schumacher (2005: 128-129), point out that quantitative research is based on some form of logical positivism that seeks to establish how things are by avoiding value judgments; while qualitative research is based on constructionism, which seeks to explain how people come to describe, explain or give an account of the world where they live. These two traditions are often seen as antagonistic and without possibilities for discussion or cooperation.

The proposal of complementarity between the two paradigms can be considered as a valid option in research; because each one of the methodologies makes important contributions to the construction of knowledge. Its rigid use, without doubts, impoverishes the process of searching for new knowledge, by preventing the incorporation into the investigative process of the benefits that each of them possesses and prevents reaching more interesting findings.

The possibilities of complementation can be based on the principles of consistency and dialectical unity. The quantitative in its hypothetico-deductive logic contributes to the process the explanation and the relation of cause and effect. In turn, the qualitative with its inductive-deductive understanding goes into the complex paths of construction and decoding of meanings of human subjectivity, which considers the individual and the group, as a result of the 
social processes that each one lives. Therefore, complementarity allows us to take advantage of the strengths of one method to compensate for the weaknesses of the other.

Taking into consideration Serrano, Blanco, Ligero, Alvira, Escobar and Sáenz (2009: 16-17), “... the combined use of both perspectives within the same investigation has become a commonly accepted place and It has even reached a point where we can talk about the "social desirability" of multi-method research".

The thematic focuses of this volume of the Revista Scientific. they clearly show its different sections, among them: the transformation of teaching practices; innovative experiences to improve the educational and teachinglearning processes within the classroom framework; virtual learning environments, information and communication technologies and the one related to environmental education. Towards there lead the questions that cross the diverse articles as testimony of the scientific results that each author proposes.

In their epistemological approaches, a journey through different methodologies, methods and techniques is appreciated. It is traveled from quantitative, qualitative or methodological completions; respecting, as previously mentioned, the nature of the object of the research carried out.

Finally, the importance of the themes of this issue of the Journal lies in the reflection on the different edges of the formative processes, in various contexts and levels of teaching. It also resides in the look at the logics in use, committed to different methodologies; which must be judged according to the success achieved in the investigations.

Keywords: publishers; research; scientific development.

Date Received: 09-01-2018

Date Acceptance: 29-01-2018 


\section{Referencias}

Erlandson, D., Harris, E., Skipper, B., \& Allen, S. (1993). Doing naturalistic inquiry: a guide to methods. Newbury Park, CA: Sage Publications, Inc.

Guba, E., \& Lincoln, Y. (2002). Paradigmas en competencia en la investigación cualitativa. En: Denman, C. y J.A. Haro (comps.). Por los rincones. Antología de métodos cualitativos en la investigación social. Hermosillo, Sonora, México: El colegio de Sonora.

Hashimoto, E., \& Saavedra, S. (2014). La complementariedad paradigmática: un nuevo enfoque para investigar. Congreso Iberoamericano de Ciencia, Tecnología, Innovación y Educación. Buenos Aires, Argentina: OEI. ISBN: 978-84-7666-210-6, págs. 21. Recuperado de:

http://www.oei.es/historico/congreso2014/memoriactei/399.pdf

McMillan, J. \& Schumacher, S. (2005). Investigación Educativa. Una introducción conceptual. Madrid: Pearson Addison Wesley, 5th Edición, págs. 656. Recuperado de:

https://revistas.uam.es/tarbiya/article/viewFile/7222/7583

Serrano, A., Blanco, F., Ligero, J., Alvira, F., Escobar, M., \& Sáenz, A. (eds.) (2009). La investigación multimétodo. Madrid, España: Universidad Complutense Madrid, págs. 94. Recuperado de:

http://eprints.ucm.es/30034/1/araceli\%20serrano\%20articulacion meto dologica. serrano blanco alvira.pdf

Stake R. (1999). Investigación con estudio de casos. Segunda edición. Madrid: Ediciones Morata. ISBN: 84-7112-422-X, págs. 155. Recuperado de: https://www.uv.mx/rmipe/files/2017/02/Investigacioncon-estudios-de-caso.pdf 